\title{
ANTECEDENTS AND CONSEQUENCES OF EMPLOYER BRAND EQUITY: TOWARD A CONCEPTUAL FRAMEWORK
}

Sultan Alshathry, University of Adelaide Marilyn Clarke, University of Adelaide

Steve Goodman, University of Adelaide

\begin{abstract}
Recent years have witnessed the use of marketing perspectives to examine the challenges confronting companies in their ongoing quest for employee attraction and retention. Specifically, branding concepts have provided a useful theoretical foundation for researchers to explore and develop a deeper understanding of employer branding. However, most of the work in this area has focused on theory transfer and scale measurement with limited description of how employer brand equity might be developed and affect employee perception. The lesson from marketing is that branding research is more important when we know what drives its value and how it affects consumers' perceptions. Using Aaker's (1991) model of brand equity as a starting point, this paper introduces a conceptual framework for employer brand equity that incorporates both antecedents and outcomes and provides a theoretical foundation for future research.
\end{abstract}

References available upon request 